Review

\title{
The Inflammasome in Host Defense
}

\section{Gang Chen and Joao H.F. Pedra*}

Center for Disease Vector Research and Department of Entomology, University of CaliforniaRiverside, Riverside, 92521, CA, USA; E-Mail: gangc@ucr.edu

* Author to whom correspondence should be addressed; E-Mail: joao.pedra@ucr.edu; Tel.: +1-951-827-7051; Fax: +1-951-827-3864.

Received: 2 December 2009; in revised form: 17 December 2009 / Accepted: 18 December 2009 / Published: 28 December 2009

\begin{abstract}
Nod-like receptors have emerged as an important family of sensors in host defense. These receptors are expressed in macrophages, dendritic cells and monocytes and play an important role in microbial immunity. Some Nod-like receptors form the inflammasome, a protein complex that activates caspase-1 in response to several stimuli. Caspase- 1 activation leads to processing and secretion of pro-inflammatory cytokines such as interleukin (IL)-1 $\beta$ and IL-18. Here, we discuss recent advances in the inflammasome field with an emphasis on host defense. We also compare differential requirements for inflammasome activation in dendritic cells, macrophages and monocytes.
\end{abstract}

Keywords: inflammasome; nod-like receptors; innate immunity

\begin{abstract}
Abbreviations
TLRs-Toll-like receptors; RLRs-Retinoic acid-inducible gene I-like receptors; NLRs-Nod-like receptors; IL — interleukin; CARD — Caspase recruitment domain; ASC — apoptosis associated speck-like protein containing a CARD; TIR-Toll-interleukin-1 receptor domain; BIR-baculovirus IAP (inhibitor of apoptosis protein) repeat; NLRC4/IPAF-interleukin $1 \beta$-converting enzyme proteaseactivating factor; LRR-leucine-rich repeat; NACHT-domain present in NAIP, CIITA, HET-E (Podospora anserine incompatibility locus protein) and telomerase associated protein; NADNACHT-associated domain; NAIP-neuronal apoptosis inhibitor protein; PYD — pyrin domain; GBPGTP binding domain; NF- $\mathrm{BB}$ - nuclear factor kappa-light-chain-enhancer of activated B cells; ESX-1 (ESAT-6 secretion system-1); ROS — Reactive oxygen species; LPS—lipopolysaccharide.
\end{abstract}




\section{Introduction}

A quick immune response defines life and death for the host. To detect infection quickly, the immune system relies on innate immunity, the first line of defense against microbial infection that engages adaptive immunity [1]. Several families of innate immune receptors have been described [2,3]. These receptor families include Toll-like receptors (TLRs), retinoic acid-inducible gene I-like receptors (RLRs), and nucleotide-binding oligomerization domain-like receptors (NLRs). TLRs are membrane bound receptors located either in the plasma membrane or on vesicles of the endocytic pathway [4]. TLRs are widely studied and detect microbial pathogens that include viruses, bacteria, protozoa, and fungi. TLR recognition of pathogen-associated molecular patterns is done via extracellular leucine-rich repeat motifs that transmit signals through the cytoplasmic Toll-interleukin (IL)-1 receptor (TIR) domain [5]. RLRs are distinct from the TLR pathway and recognize viral RNA present within the cytoplasm [3]. RLRs proteins have a RNA-binding helicase domain and two amino (N)-terminal caspase recruitment domains (CARDs) for propagation to the interferon-regulatory factor and NF- $\mathrm{KB}$ signaling pathways [6,7].

Figure 1. NLR domain structures. The domain structures of seven NLR members are shown. The CARD domain depicted in CIITA is only present in some splice forms. Abbreviations: BIR, baculovirus IAP (inhibitor of apoptosis protein) repeat; CARD, caspase-recruitment domain; CIITA, major histocompatibility complex (MHC) class II transactivator; FIIND, domain with a function to find; NLRC4/IPAF, interleukin $1 \beta$-converting enzyme protease-activating factor; LRR, leucine-rich repeat; NACHT, domain present in NAIP, CIITA, HET-E (incompatibility locus protein from Podospora anserine) and telomerase associated protein; NAD, NACHT-associated domain; NAIP, neuronal apoptosis inhibitor protein; PYD, pyrin domain; GBP, GTP binding domain.

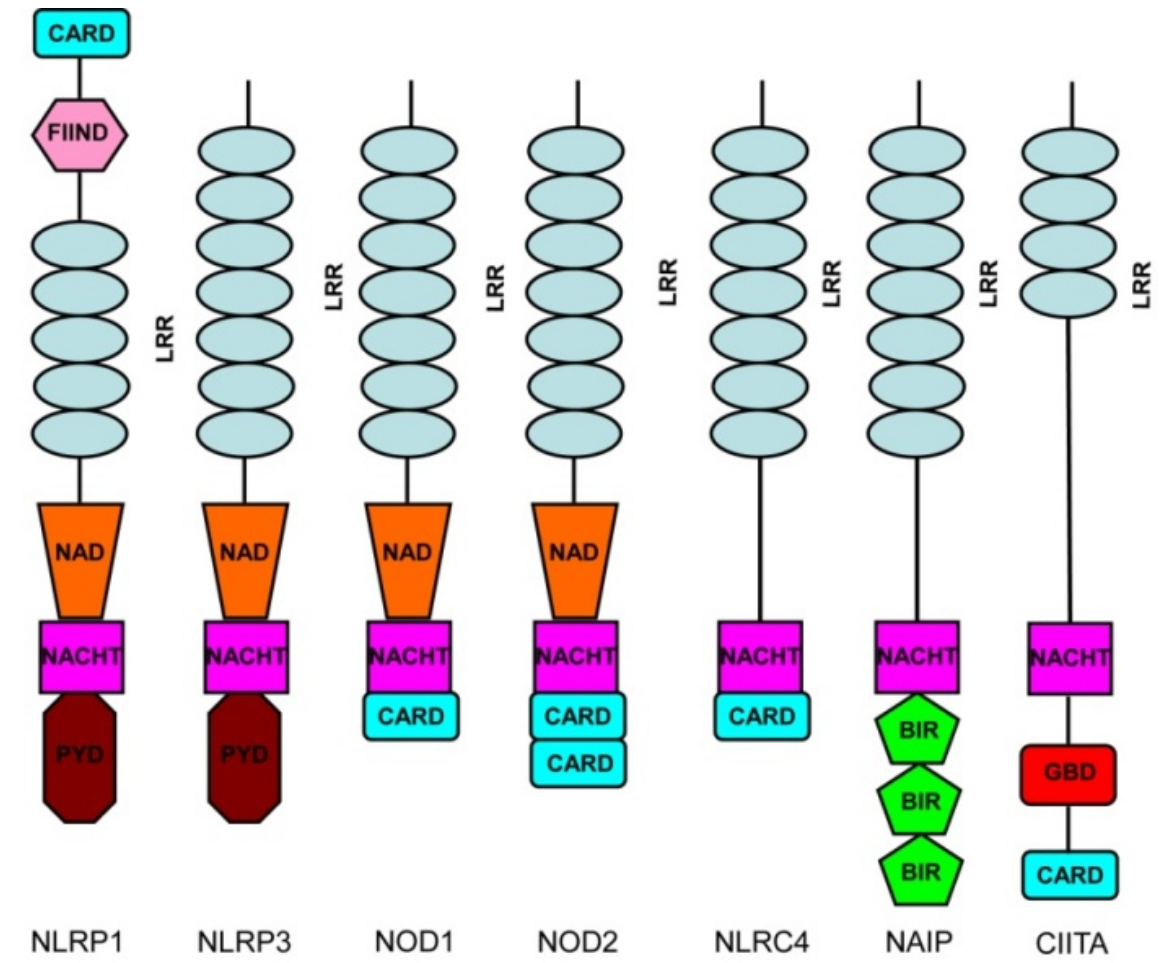


NLRs are a family of intracellular sensors that have key roles in innate immunity and inflammation [8-11]. NLRs are defined by an architecture that contains a $N$-terminus, a middle nucleotide binding and oligomerization domain, and a leucine-rich repeat domain that is variable in the repeats composition and number (Figure 1). A number of NLR family members can form multiprotein complexes, called inflammasomes, and are capable of activating the cysteine protease caspase- 1 in response to a wide range of stimuli including both microbial and self-molecules. NLRs induce the recruitment of the adaptor molecule ASC (apoptosis associated speck-like protein containing a CARD), leading to the processing and activation of pro-IL-1 $\beta$ and IL-18 through caspase-1. NLRs are mostly cytosolic and structurally related to the disease resistant protein family ( $R$ protein) [12]. In this review we will discuss the mechanisms by which the inflammasome is activated in cells. A greater emphasis will be placed on a broader function of the inflammasome in host defense. We will elaborate on the cross-talk between the inflammasome and other signaling pathways. We also review mechanisms of inflammasome activation according to the environment in which each cell type is located. We make a distinction between findings observed in macrophages, dendritic cells and monocytes. We apologize in advance to those whose work could not be cited due to space constraints.

\section{The Inflammasome}

In humans the NLR family is composed of 22 members [10]. They are divided into subfamilies according to their $\mathrm{N}$-terminal effector domains. The effector domains lead to inflammatory caspase or NF- $\kappa \mathrm{B}$ activation. In humans, 14 NLR members share a pyrin effector domain. Five other members are part of the NOD subfamily. CIITA, NLRC4/IPAF and the BIR-containing NAIP form the remaining NLR members. Earlier nomenclature was confusing; however, a standardized nomenclature has recently been proposed, and we will use it throughout this review [13]. NLR molecules have been shown to form a complex with caspase-1 and the adaptor molecule ASC termed the inflammasome. The term inflammasome was coined to describe a complex of proteins that activates caspase-1 and the cytokine IL-1 $\beta$. Inflammasome is derived from the word inflammation and the suffix "some", which is used to define molecular complexes [10]. This term was also chosen to highlight functional similarities with another platform that triggers apoptosis - the apoptosome [14]. The central effector molecule of the inflammasome is the cysteine protease caspase- 1 that, upon activation cleaves cytosolic pro-IL-1 $\beta$, pro-IL-18 to their active forms. Recent studies have shown that the NLRP1, NLRP3, and NLRC4 inflammasomes have a clear role in host defense (Figure 2). These distinct inflammasomes are described below. 
Figure 2. Mechanisms of inflammasome activation. Three different NLRs regulate the inflammasome. The NLRC4 inflammasome is triggered by microbial components secreted by bacterial secretion systems. The NLRP1/NALP1 inflammasome is associated with susceptibility to the Bacillus anthracis lethal toxin. Microbial toxins and danger signals trigger the NLRP3/NALP3 inflammasome. Crystals cause lysosome damage and protein leakage to the cytosol. Response to the NLRP3/NALP3 inflammasome triggers reactive oxygen species and potassium efflux although it is not clear how the signaling cascade operates.

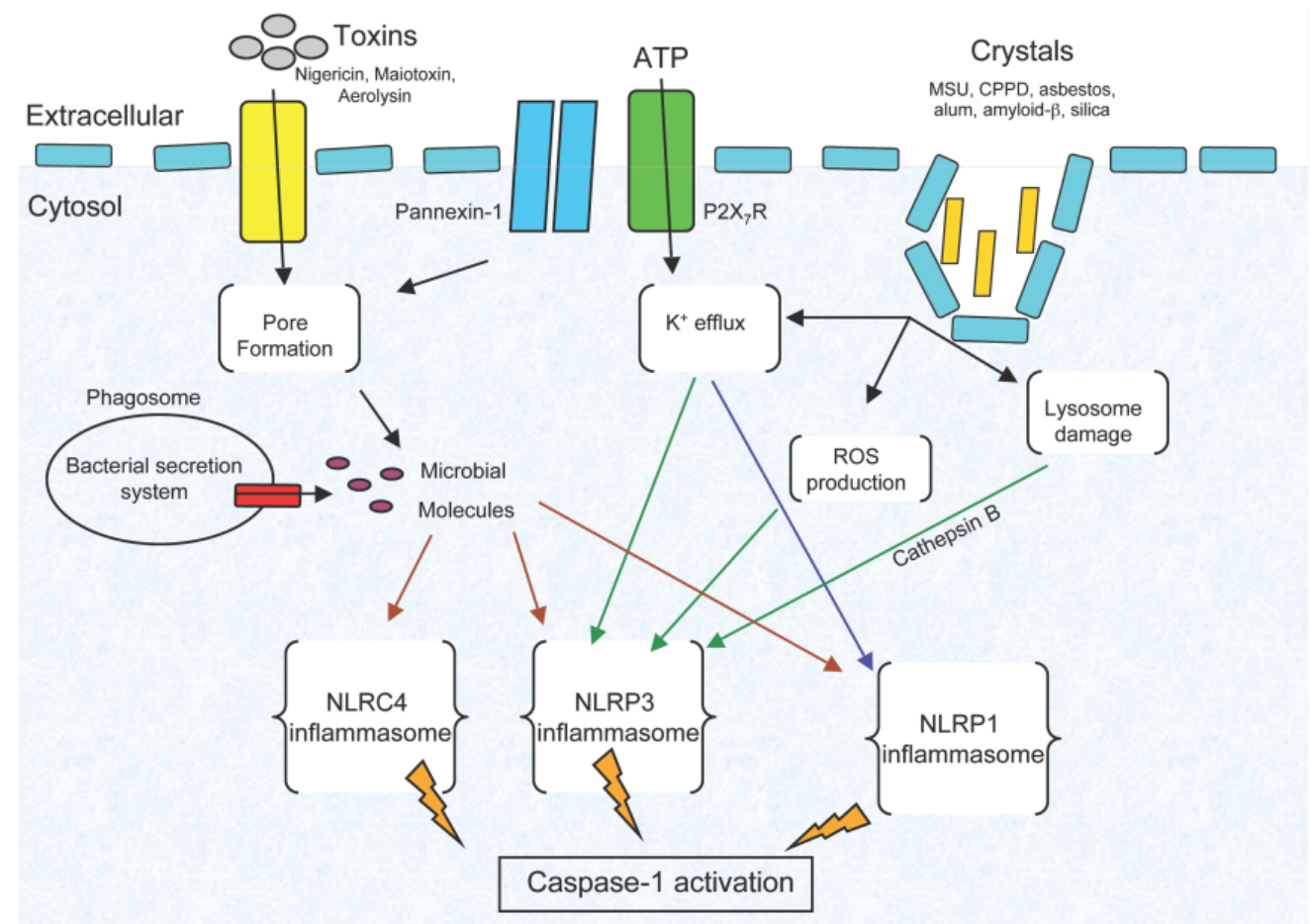

\subsection{The NLRP1/NALP1 Inflammasome}

The NLRP1/NALP1 inflammasome (also known as DEFCAP, NAC, CARD7 and CLR17.1) is formed as a reconstituted complex enriched for caspase-1, caspase-5, and the adaptor molecule ASC [15]. Reed and colleagues have demonstrated that the minimal components for inflammasome activation are NLRP1/NALP1 and caspase-1 in the presence of ribonucleotides [16]. The bacterial cell wall component muramyl dipeptide (MDP) strongly activates the inflammasome in-vitro, although direct binding of MDP to NLRP1/NALP1 was not demonstrated.

The adaptor molecule ASC was not required for NLRP1/NALP1 inflammasome activation although its presence did enhance caspase-1 activation. NLRP1/NALP1 also plays a role in anthrax immunity [17-23]. Bacillus anthracis lethal toxin (LT) can induce caspase-1-dependent cell death of macrophages. Boyden and Dietrich revealed that the NLRP1/NALP1b gene, one of three paralogues of $N L R P 1 / N A L P 1$ in mice, is responsible for macrophage susceptibility to LT [18]. Hsu et al. have also shown that NLRP1/NALP1 plays a role in LT-induced caspase-1-dependent IL-1 $\beta$ secretion in response to intact $B$. anthracis [24]. This study demonstrated that NOD2 was required for $B$. anthracisinduced IL-1 $\beta$ secretion, suggesting that NOD2 may interact with the NLRP1/NALP1 inflammasome. Interestingly, the group of Tschopp has demonstrated that mouse effector and memory $\mathrm{CD} 4^{+} \mathrm{T}$ cells 
abolish macrophage inflammasome-mediated caspase-1 activation and interleukin-1 $\beta$. Inhibition of the inflammasome is observed for NLRP1/NALP1, NLRP3/NALP3 and the NLRC4/IPAF protein complexes [25].

\subsection{The NLRC4/Ipaf Inflammasome}

The NLRC4/Ipaf inflammasome (also known as CARD12, CLR2.1 and CLAN) is important for caspase-1 activation in response to Salmonella, Pseudomonas, Legionella, Listeria, Anaplasma and Shigella [26-38]. NLRC4/IPAF responds to the presence of flagellin within the macrophage cytosol during infection by Salmonella [27,30,39], Legionella [26,40-47] and Pseudomonas [29,33,34]. Shigella, however, does not express flagellin, suggesting that NLRC4/IPAF may signal through a molecule independently of flagellin expression [36,37]. For Legionella infection, Vance and colleagues [47] have generated mice deficient in the intracellular sensor Naip5/Birc1e/NLRB1 and have elegantly demonstrated that these mice fail to activate the inflammasome in response to a segment of the carboxyl terminus of flagellin. Signaling mechanisms that form the NLRC4/IPAF inflammasome has been recently expanded. Using Legionella as a model pathogen, Akhter et al. [48] have demonstrated that caspase-7 was activated downstream of the NLRC4/ IPAF inflammasome and required caspase- 1 activation. Caspase- 7 activation was mediated by flagellin and required a functional Naip5 [49,50].

\subsection{The NLRP3/NALP3 Inflammasome}

The NLRP3/NALP3 (also known as cryopyrin, CIAS1, PYPAF1 and CLR1.1) is the best-studied inflammasome and is activated by chemically and structurally diverse stimuli-i.e., malarial hemozoin, crystal structures and fungal toxins, viral RNA, among others [8,51-68]. LPS and extracellular ATP stimulate caspase-1 in a NLRP3/NALP3 dependent fashion [54,55]. ATP activates the purinergic receptor $\mathrm{P} 2 \mathrm{X} 7$, which recruits another hemichannel-pannexin-1. Pannexin-1 forms a larger pore of the $\mathrm{P} 2 \mathrm{X} 7$ purinergic receptor upon activation and is important for caspase-1 activation [69-72]. Pannexin-1 channels can be activated by high extracellular $\mathrm{K}^{+}$. Activation of pannexin-1 channels by extracellular $\mathrm{K}^{+}$occurs in cells voltage-clamped to the resting membrane potential. Therefore, it cannot occur due to the depolarization resulting from the elimination of the transmembrane $\mathrm{K}^{+}$gradient. It is unclear whether $\mathrm{K}^{+}$activation of pannexin 1 channels occurs in vivo. Despite a well-documented role of $\mathrm{K}^{+}$ions in the NLRP3/NALP3 inflammasome in-vitro, the mechanism of action is poorly understood.

The NLRP3/NALP3 inflammasome assembly occurs when potassium efflux inducing agents such as nigericin, Listeria LLO, Aeromonas aerolysin, and maiotoxin induce the formation of plasma membrane pores [53,55]. Mycobacterium tuberculosis, through its ESX-1 secretion system, has been shown to activate the NLRP3/NALP3 inflammasome [73]. DNA, bacterial RNA and the antiviral imidazoquinoline compounds R837 and R848 also induce the NLRP3/NALP3 inflammasome [57,59]. However, four independent groups have recently demonstrated that immune detection of foreign dsDNA in the cytoplasm occurs primarily through the AIM2 - a member of the HIN-200 family of IFN-inducible proteins that recruits ASC and caspase-1 [74-77]. Particulate matter such as gout and pseudogout-associated uric acid crystals, monosodium urate and calcium pyrophosphate dihydrate and 
fungal infection activate the NLRP3/NALP3 inflammasome in a P2X7-independent manner [49,56,78-82]. Silica and aluminum salt crystals activate the NLRP3/NALP3 inflammasome through phagocytosis [60]. Crystals induced lysosome swelling, damage and leakage of proteins to the cytosol. The inhibition of a lysosomal protein -cathepsin B- leads to a significant decrease in NLRP3/NALP3 activation $[58,83,84]$. Two events that appear to be required for both toxin- and crystal-mediated NLRP3/NALP3 inflammasome activation are efflux of intracellular potassium and the generation of reactive oxygen species (ROS). A decrease in intracellular potassium concentrations may be required for assembly of the NLRP3/NALP3 inflammasome, however, the precise role of potassium in this process is unknown [85]. Similarly blockade of ROS production using chemical inhibitors has been shown to mitigate the ability of silica, asbestos and ATP to activate the NLRP3/NALP3 inflammasome [85-88]. $\mathrm{Ng}$ and colleagues demonstrated that uric acid crystals could directly engage cholesterol rich cellular membranes resulting in the activation of a Syk kinase-dependent signaling cascade [89]. Syk kinase signaling was also coupled to the NLRP3/NALP3 inflammasome for anti-fungal host defense.

\section{Inflammasome Activation Requirements}

Dendritic cells, macrophages and circulating monocytes must respond to microbial threats and are essential to host defense. Inflammasome activation in monocytes and dendritic cells and macrophages are different. Two fundamental differences exist for inflammasome activation in dendritic cells, macrophages and circulating monocytes. While monocytes have constitutively activated caspase- 1 , the activation of caspase- 1 in dendritic cells and macrophages needs to be induced.

Figure 3. Differential requirements for inflammasome activation in immune cells. Caspase- 1 is constitutively activated in circulating monocytes and release mature IL-1 $\beta$ after a single stimulation with TLR ligands such as LPS. IL-1 $\beta$ secretion is induced by endogenously released ATP. Dendritic cells and macrophages, however, need double stimulation: the first stimulus may be a TLR ligand (e.g., LPS), which induces transcription of IL-1 $\beta$ via NF- $\kappa$ B. The second stimulus (e.g., exogenous ATP, bacterial toxins) triggers NLR and caspase- 1 activation followed by IL-1 $\beta$ secretion.

Monocytes

Macrophages/DCs

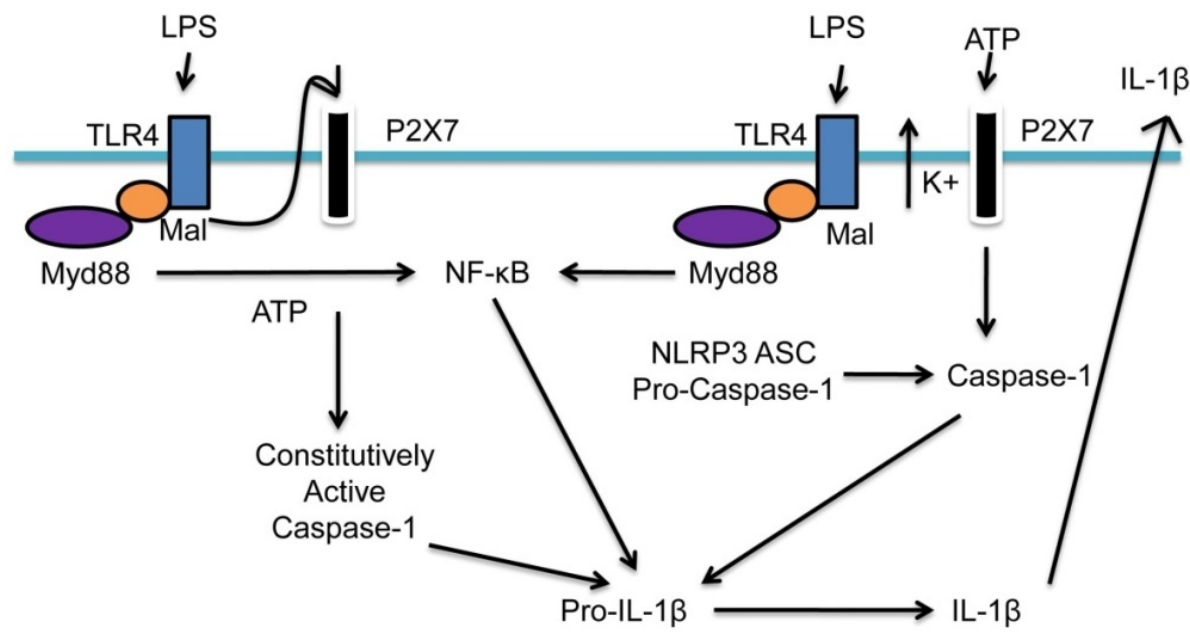


Furthermore, monocytes are capable of releasing endogenous ATP [90]—an important molecule for inflammasome activation, whereas the lack of endogenous ATP by macrophages and dendritic cells renders these cells incapable of IL-1 $\beta$ secretion with one single stimulus. Netea and colleagues [91] have recently clarified these mechanisms. Monocytes only need a single TLR stimulus for IL-1 $\beta$ secretion, whereas dendritic cells and macrophages need a double stimulation-TLR (e.g., LPS) and NLR (e.g., ATP) stimuli (Figure 3). The reason for this differential regulation is poorly understood. Current evidence suggests an adaptation of each cell type to their respective environment. Circulating monocytes function in a pathogen-free environment and must promptly respond to a microbial threat. Dendritic cells and macrophages are confined to a non-sterile environment and are constantly exposed to microbial pathogens. Therefore, a second checkpoint mechanism is necessary to avoid deleterious inflammation.

The difference in inflammasome activation requirements does not seem to be restricted to macrophages, dendritic cells and monocytes. In contrast to monocytes and macrophages, in which low intracellular $\mathrm{K}^{+}$triggers inflammasome activation, neurons and astrocytes activate caspase-1 by high intracellular $\mathrm{K}^{+}$[92]. In epithelial cells, which do not secrete high levels of IL-1 $\beta$, caspase-1 enhances lipid metabolism and is required for optimal growth of the intracellular bacterium Chlamydiae [68]. Mast cells were identified as the main cell population responsible for IL- $1 \beta$ in the skin of cryopyrin-associated periodic syndrome patients. Unlike normal mast cells that required stimulation with pro-inflammatory stimuli for IL-1 $\beta$ production, resident mast cells from cryopyrin-associated periodic syndrome patients constitutively produced IL-1 $\beta$ via the NLRP3 inflammasome [93]. Collectively, these findings demonstrate that each cell type commits the inflammasome to the immediate environment in which they are located. This differential requirement for inflammasome activation operates to prevent accidental or uncontrolled inflammation, which may have devastated consequences for the host. A better understanding of the inflammasome activation in cells other than macrophages and dendritic cells may have significant ramifications for the treatment of infectious diseases and inflammatory disorders.

\section{Conclusions}

The cytoplasm was thought for a long time to be a safe haven for pathogenic microbes. Once viruses and intracellular bacteria evaded cell surface innate immune receptors, they could establish themselves into the cell interior, and replicate in it unabated. Recent findings, however, have challenged this line of thinking. Newly discovered cytoplasmic defenses such as NLRs have been show to preserve the cytosolic environment against pathogenic microbes. The field of NLRs and the inflammasome has blossomed into an important area of innate immunity and inflammation. We have attempted to describe these latest findings with an emphasis on host defense. Several fundamental questions remain unanswered in the NLR and the inflammasome field. The first and foremost fundamental issue is related to whether NLR recognition of pathogen-associated molecular patterns is direct or indirect. A second issue relates to the scope of the studies in field of the inflammasome. Most studies have been focused on macrophages and dendritic cells and three types of inflammasomeNLRP1/NALP1, NLRP3/NALP3, and NLRC4/IPAF inflammasome. We reason that it is important to investigate other types of inflammasome in cells other than macrophages and dendritic cells for the 
safer design of therapeutics. A third issue that needs to be explored is the connection of the inflammasome with adaptive immunity. Although a few papers have emerged recently [25,94], it is poorly established how the inflammasome engages adaptive immunity in host defense. There are many roles for the inflammasome yet to be examined. The importance of the inflammasome in host defense makes this protein complex an attractive target for therapeutic intervention in microbial immunity.

\section{Acknowledgements}

This work was supported by a cooperative agreement K01 CK000101 from the Centers for Disease Control and Prevention (JHFP).

\section{References and Notes}

1. Palm, N.W.; Medzhitov, R. Pattern recognition receptors and control of adaptive immunity. Immunol. Rev. 2009, 227, 221-233.

2. Medzhitov, R. Approaching the asymptote: 20 years later. Immunity 2009, 30, 766-775.

3. Creagh, E.M.; O'Neill, L.A. TLRs, NLRs and RLRs: a trinity of pathogen sensors that co-operate in innate immunity. Trends Immunol. 2006, 27, 352-357.

4. Rakoff-Nahoum, S.; Medzhitov, R. Toll-like receptors and cancer. Nat. Rev. Cancer 2009, 9, 57-63.

5. van Duin, D.; Medzhitov, R.; Shaw, A.C. Triggering TLR signaling in vaccination. Trends Immunol. 2006, 27, 49-55.

6. Nakhaei, P.; Genin, P.; Civas, A.; Hiscott, J. RIG-I-like receptors: sensing and responding to RNA virus infection. Semin. Immunol. 2009, 21, 215-222.

7. Kawai, T.; Akira, S. Toll-like receptor and RIG-I-like receptor signaling. Ann. NY Acad. Sci. 2008, 1143, 1-20.

8. Tiemi Shio, M.; Eisenbarth, S.C.; Savaria, M.; Vinet, A.F.; Bellemare, M.J.; Harder, K.W.; Sutterwala, F.S.; Bohle, D.S.; Descoteaux, A.; Flavell, R.A.; Olivier, M. Malarial hemozoin activates the NLRP3 inflammasome through Lyn and Syk kinases. PLoS Pathog. 2009, 5, e1000559.

9. Brodsky, I.E.; Monack, D. NLR-mediated control of inflammasome assembly in the host response against bacterial pathogens. Semin. Immunol. 2009, 21, 199-207.

10. Martinon, F.; Mayor, A.; Tschopp, J. The inflammasomes: guardians of the body. Annu. Rev. Immunol. 2009, 27, 229-265.

11. Pedra, J.H.; Cassel, S.L.; Sutterwala, F.S. Sensing pathogens and danger signals by the inflammasome. Cur. Opin. Immunol. 2009, 21, 10-16.

12. Shirasu, K. The HSP90-SGT1 chaperone complex for NLR immune sensors. Annu. Rev. Plant Biol. 2009, 60, 139-164.

13. Ting, J.P.; Lovering, R.C.; Alnemri, E.S.; Bertin, J.; Boss, J.M.; Davis, B.K.; Flavell, R.A.; Girardin, S.E.; Godzik, A.; Harton, J.A.; Hoffman, H.M.; Hugot, J.P.; Inohara, N.; Mackenzie, A.; Maltais, L.J.; Nunez, G.; Ogura, Y.; Otten, L.A.; Philpott, D.; Reed, J.C.; Reith, W.; Schreiber, S.; Steimle, V.; Ward, P.A. The NLR gene family: a standard nomenclature. Immunity 2008, 28, 285-287. 
14. Proell, M.; Riedl, S.J.; Fritz, J.H.; Rojas, A.M.; Schwarzenbacher, R. The Nod-like receptor (NLR) family: a tale of similarities and differences. PLoS One 2008, 3, e2119.

15. Martinon, F.; Burns, K.; Tschopp, J. The inflammasome: a molecular platform triggering activation of inflammatory caspases and processing of proIL-beta. Mol. Cell 2002, 10, 417-426.

16. Faustin, B.; Lartigue, L.; Bruey, J.M.; Luciano, F.; Sergienko, E.; Bailly-Maitre, B.; Volkmann, N.; Hanein, D.; Rouiller, I.; Reed, J.C. Reconstituted NALP1 inflammasome reveals two-step mechanism of caspase-1 activation. Mole. Cell 2007, 25, 713-724.

17. Wickliffe, K.E.; Leppla, S.H.; Moayeri, M. Anthrax lethal toxin-induced inflammasome formation and caspase-1 activation are late events dependent on ion fluxes and the proteasome. Cell. Microbiol. 2008, 10, 332-343.

18. Boyden, E.D.; Dietrich, W.F. Nalp1b controls mouse macrophage susceptibility to anthrax lethal toxin. Nat. Genet. 2006, 38, 240-244.

19. Reig, N.; Jiang, A.; Couture, R.; Sutterwala, F.S.; Ogura, Y.; Flavell, R.A.; Mellman, I.; van der Goot, F.G. Maturation modulates caspase-1-independent responses of dendritic cells to Anthrax lethal toxin. Cell. Microbiol. 2008, 10, 1190-1207.

20. Squires, R.C.; Muehlbauer, S.M.; Brojatsch, J. Proteasomes control caspase-1 activation in anthrax lethal toxin-mediated cell killing. J. Biol. Chem. 2007, 282, 34260-34267.

21. Liao, K.C.; Mogridge, J. Expression of Nlrplb inflammasome components in human fibroblasts confers susceptibility to anthrax lethal toxin. Infect. Immun. 2009, 77, 4455-4462.

22. Newman, Z.L.; Leppla, S.H.; Moayeri, M. CA-074Me protection against anthrax lethal toxin. Infect. Immun. 2009, 77, 4327-4336.

23. Nour, A.M.; Yeung, Y.G.; Santambrogio, L.; Boyden, E.D.; Stanley, E.R.; Brojatsch, J. Anthrax lethal toxin triggers the formation of a membrane-associated inflammasome complex in murine macrophages. Infect. Immun. 2009, 77, 1262-1271.

24. Hsu, L.C.; Ali, S.R.; McGillivray, S.; Tseng, P.H.; Mariathasan, S.; Humke, E.W.; Eckmann, L.; Powell, J.J.; Nizet, V.; Dixit, V.M.; Karin, M. A NOD2-NALP1 complex mediates caspase-1dependent IL-1beta secretion in response to Bacillus anthracis infection and muramyl dipeptide. Proc. Natl. Acad. Sci. USA 2008, 105, 7803-7808.

25. Guarda, G.; Dostert, C.; Staehli, F.; Cabalzar, K.; Castillo, R.; Tardivel, A.; Schneider, P.; Tschopp, J. T cells dampen innate immune responses through inhibition of NLRP1 and NLRP3 inflammasomes. Nature 2009, 460, 269-273.

26. Amer, A.; Franchi, L.; Kanneganti, T.D.; Body-Malapel, M.; Ozoren, N.; Brady, G.; Meshinchi, S.; Jagirdar, R.; Gewirtz, A.; Akira, S.; Nunez, G. Regulation of Legionella phagosome maturation and infection through flagellin and host Ipaf. J. Biol. Chem. 2006, 281, 35217-35223.

27. Franchi, L.; Amer, A.; Body-Malapel, M.; Kanneganti, T.D.; Ozoren, N.; Jagirdar, R.; Inohara, N.; Vandenabeele, P.; Bertin, J.; Coyle, A.; Grant, E.P.; Nunez, G. Cytosolic flagellin requires Ipaf for activation of caspase-1 and interleukin 1beta in Salmonella-infected macrophages. Nat. Immunol. 2006, 7, 576-582.

28. Mariathasan, S.; Newton, K.; Monack, D.M.; Vucic, D.; French, D.M.; Lee, W.P.; Roose-Girma, M.; Erickson, S.; Dixit, V.M. Differential activation of the inflammasome by caspase-1 adaptors ASC and Ipaf. Nature 2004, 430, 213-218. 
29. Franchi, L.; Stoolman, J.; Kanneganti, T.D.; Verma, A.; Ramphal, R.; Nunez, G. Critical role for Ipaf in Pseudomonas aeruginosa-induced caspase-1 activation. Eur. J. Immunol. 2007, 37, 3030-3039.

30. Miao, E.A.; Alpuche-Aranda, C.M.; Dors, M.; Clark, A.E.; Bader, M.W.; Miller, S.I.; Aderem, A. Cytoplasmic flagellin activates caspase-1 and secretion of interleukin 1beta via Ipaf. Nat. Immunol. 2006, 7, 569-575.

31. Warren, S.E.; Mao, D.P.; Rodriguez, A.E.; Miao, E.A.; Aderem, A. Multiple Nod-like receptors activate caspase 1 during Listeria monocytogenes infection. J. Immunol. 2008, 180, 7558-7564.

32. Fink, S.L.; Bergsbaken, T.; Cookson, B.T. Anthrax lethal toxin and Salmonella elicit the common cell death pathway of caspase-1-dependent pyroptosis via distinct mechanisms. Proc. Natl. Acad. Sci. USA 2008, 105, 4312-4317.

33. Miao, E.A.; Ernst, R.K.; Dors, M.; Mao, D.P.; Aderem, A. Pseudomonas aeruginosa activates caspase 1 through Ipaf. Proc. Natl. Acad. Sci. USA 2008, 105, 2562-2567.

34. Sutterwala, F.S.; Mijares, L.A.; Li, L.; Ogura, Y.; Kazmierczak, B.I.; Flavell, R.A. Immune recognition of Pseudomonas aeruginosa mediated by the IPAF/NLRC4 inflammasome. J. Exp. Med. 2007, 204, 3235-3245.

35. Franchi, L.; Stoolman, J.; Kanneganti, T.D.; Verma, A.; Ramphal, R.; Nunez, G. Critical role for Ipaf in Pseudomonas aeruginosa-induced caspase-1 activation. Eur. J. Immunol. 2007, 37, 3030-3039.

36. Suzuki, T.; Nunez, G. A role for Nod-like receptors in autophagy induced by Shigella infection. Autophagy 2008, 4, 73-75.

37. Suzuki, T.; Franchi, L.; Toma, C.; Ashida, H.; Ogawa, M.; Yoshikawa, Y.; Mimuro, H.; Inohara, N.; Sasakawa, C.; Nunez, G. Differential regulation of caspase-1 activation, pyroptosis, and autophagy via Ipaf and ASC in Shigella-infected macrophages. PLoS Pathog. 2007, 3, e111.

38. Pedra, J.H.; Sutterwala, F.S.; Sukumaran, B.; Ogura, Y.; Qian, F.; Montgomery, R.R.; Flavell, R.A.; Fikrig, E. ASC/PYCARD and caspase-1 regulate the IL-18/IFN-\{gamma\} axis during anaplasma phagocytophilum infection. J. Immunol. 2007, 179, 4783-4791.

39. Sun, Y.H.; Rolan, H.G.; Tsolis, R.M. Injection of flagellin into the host cell cytosol by Salmonella enterica serotype typhimurium. J. Biol. Chem. 2007, 282, 33897-33901.

40. Diez, E.; Lee, S.H.; Gauthier, S.; Yaraghi, Z.; Tremblay, M.; Vidal, S.; Gros, P. Birc1e is the gene within the Lgn1 locus associated with resistance to Legionella pneumophila. Nat. Genet. 2003, 33, 55-60.

41. Growney, J.D.; Dietrich, W.F. High-resolution genetic and physical map of the Lgn1 interval in C57BL/6J implicates Naip2 or Naip5 in Legionella pneumophila pathogenesis. Genome Res. 2000, 10, 1158-1171.

42. Wright, E.K.; Goodart, S.A.; Growney, J.D.; Hadinoto, V.; Endrizzi, M.G.; Long, E.M.; Sadigh, K.; Abney, A.L.; Bernstein-Hanley, I.; Dietrich, W.F. Naip5 affects host susceptibility to the intracellular pathogen Legionella pneumophila. Curr. Biol. 2003, 13, 27-36.

43. Zamboni, D.S.; Kobayashi, K.S.; Kohlsdorf, T.; Ogura, Y.; Long, E.M.; Vance, R.E.; Kuida, K.; Mariathasan, S.; Dixit, V.M.; Flavell, R.A.; Dietrich, W.F.; Roy, C.R. The Bircle cytosolic pattern-recognition receptor contributes to the detection and control of Legionella pneumophila infection. Nat. Immunol. 2006, 7, 318-325. 
44. Ren, T.; Zamboni, D.S.; Roy, C.R.; Dietrich, W.F.; Vance, R.E. Flagellin-deficient Legionella mutants evade caspase-1- and Naip5-mediated macrophage immunity. PLoS Pathog. 2006, 2, e18.

45. Molofsky, A.B.; Byrne, B.G.; Whitfield, N.N.; Madigan, C.A.; Fuse, E.T.; Tateda, K.; Swanson, M.S. Cytosolic recognition of flagellin by mouse macrophages restricts Legionella pneumophila infection. J. Exper. Med. 2006, 203, 1093-1104.

46. Lamkanfi, M.; Amer, A.; Kanneganti, T.D.; Munoz-Planillo, R.; Chen, G.; Vandenabeele, P.; Fortier, A.; Gros, P.; Nunez, G. The Nod-like receptor family member Naip5/Birc1e restricts Legionella pneumophila growth independently of caspase-1 activation. J. Immunol. 2007, 178, 8022-8027.

47. Lightfield, K.L.; Persson, J.; Brubaker, S.W.; Witte, C.E.; von Moltke, J.; Dunipace, E.A.; Henry, T.; Sun, Y.H.; Cado, D.; Dietrich, W.F.; Monack, D.M.; Tsolis, R.M.; Vance, R.E. Critical function for Naip5 in inflammasome activation by a conserved carboxy-terminal domain of flagellin. Nat. Immunol. 2008, 9, 1171-1178.

48. Akhter, A.; Gavrilin, M.A.; Frantz, L.; Washington, S.; Ditty, C.; Limoli, D.; Day, C.; Sarkar, A.; Newland, C.; Butchar, J.; Marsh, C.B.; Wewers, M.D.; Tridandapani, S.; Kanneganti, T.D.; Amer, A.O. Caspase-7 activation by the Nlrc4/Ipaf inflammasome restricts Legionella pneumophila infection. PLoS Pathog. 2009, 5, e1000361.

49. Lamkanfi, M.; Malireddi, R.K.; Kanneganti, T.D. Fungal zymosan and mannan activate the cryopyrin inflammasome. J. Biol. Chem. 2009, 284, 20574-20581.

50. Lamkanfi, M.; Kanneganti, T.D.; Van Damme, P.; Vanden Berghe, T.; Vanoverberghe, I.; Vandekerckhove, J.; Vandenabeele, P.; Gevaert, K.; Nunez, G. Targeted peptidecentric proteomics reveals caspase-7 as a substrate of the caspase-1 inflammasomes. Mol. Cell. Proteomics 2008, 7, 2350-2363.

51. Allen, I.C.; Scull, M.A.; Moore, C.B.; Holl, E.K.; McElvania-TeKippe, E.; Taxman, D.J.; Guthrie, E.H.; Pickles, R.J.; Ting, J.P. The NLRP3 inflammasome mediates in vivo innate immunity to influenza A virus through recognition of viral RNA. Immunity 2009, 30, 556-565.

52. Meissner, F.; Molawi, K.; Zychlinsky, A. Superoxide dismutase 1 regulates caspase-1 and endotoxic shock. Nat. Immunol. 2008, 9, 866-872.

53. Gurcel, L.; Abrami, L.; Girardin, S.; Tschopp, J.; van der Goot, F.G. Caspase-1 activation of lipid metabolic pathways in response to bacterial pore-forming toxins promotes cell survival. Cell 2006, 126, 1135-1145.

54. Sutterwala, F.S.; Ogura, Y.; Szczepanik, M.; Lara-Tejero, M.; Lichtenberger, G.S.; Grant, E.P.; Bertin, J.; Coyle, A.J.; Galan, J.E.; Askenase, P.W.; Flavell, R.A. Critical role for NALP3/CIAS1/Cryopyrin in innate and adaptive immunity through its regulation of caspase-1. Immunity 2006, 24, 317-327.

55. Mariathasan, S.; Weiss, D.S.; Newton, K.; McBride, J.; O'Rourke, K.; Roose-Girma, M.; Lee, W.P.; Weinrauch, Y.; Monack, D.M.; Dixit, V.M. Cryopyrin activates the inflammasome in response to toxins and ATP. Nature 2006, 440, 228-232.

56. Martinon, F.; Petrilli, V.; Mayor, A.; Tardivel, A.; Tschopp, J. Gout-associated uric acid crystals activate the NALP3 inflammasome. Nature 2006, 440, 237-241. 
57. Kanneganti, T.D.; Ozoren, N.; Body-Malapel, M.; Amer, A.; Park, J.H.; Franchi, L.; Whitfield, J.; Barchet, W.; Colonna, M.; Vandenabeele, P.; Bertin, J.; Coyle, A.; Grant, E.P.; Akira, S.; Nunez, G. Bacterial RNA and small antiviral compounds activate caspase-1 through cryopyrin/Nalp3. Nature 2006, 440, 233-236.

58. Willingham, S.B.; Bergstralh, D.T.; O'Connor, W.; Morrison, A.C.; Taxman, D.J.; Duncan, J.A.; Barnoy, S.; Venkatesan, M.M.; Flavell, R.A.; Deshmukh, M.; Hoffman, H.M.; Ting, J.P. Microbial pathogen-induced necrotic cell death mediated by the inflammasome components CIAS1/cryopyrin/NLRP3 and ASC. Cell Host Microbe 2007, 2, 147-159.

59. Muruve, D.A.; Petrilli, V.; Zaiss, A.K.; White, L.R.; Clark, S.A.; Ross, P.J.; Parks, R.J.; Tschopp, J. The inflammasome recognizes cytosolic microbial and host DNA and triggers an innate immune response. Nature 2008, 452, 103-107.

60. Hornung, V.; Bauernfeind, F.; Halle, A.; Samstad, E.O.; Kono, H.; Rock, K.L.; Fitzgerald, K.A.; Latz, E. Silica crystals and aluminum salts activate the NALP3 inflammasome through phagosomal destabilization. Nat. Immunol. 2008.

61. Eisenbarth, S.C.; Colegio, O.R.; O'Connor, W.; Sutterwala, F.S.; Flavell, R.A. Crucial role for the Nalp3 inflammasome in the immunostimulatory properties of aluminium adjuvants. Nature 2008, 453, 1122-1126.

62. Halle, A.; Hornung, V.; Petzold, G.C.; Stewart, C.R.; Monks, B.G.; Reinheckel, T.; Fitzgerald, K.A.; Latz, E.; Moore, K.J.; Golenbock, D.T. The NALP3 inflammasome is involved in the innate immune response to amyloid-beta. Nat. Immunol. 2008.

63. Dostert, C.; Guarda, G.; Romero, J.F.; Menu, P.; Gross, O.; Tardivel, A.; Suva, M.L.; Stehle, J.C.; Kopf, M.; Stamenkovic, I.; Corradin, G.; Tschopp, J. Malarial hemozoin is a Nalp3 inflammasome activating danger signal. PLoS One 2009, 4, e6510.

64. Bostanci, N.; Emingil, G.; Saygan, B.; Turkoglu, O.; Atilla, G.; Curtis, M.A.; Belibasakis, G.N. Expression and regulation of the NALP3 inflammasome complex in periodontal diseases. Clin. Exp. Immunol. 2009, 157, 415-422.

65. Huang, M.T.; Taxman, D.J.; Holley-Guthrie, E.A.; Moore, C.B.; Willingham, S.B.; Madden, V.; Parsons, R.K.; Featherstone, G.L.; Arnold, R.R.; O'Connor, B.P.; Ting, J.P. Critical role of apoptotic speck protein containing a caspase recruitment domain (ASC) and NLRP3 in causing necrosis and ASC speck formation induced by porphyromonas gingivalis in human cells. $J$. Immunol. 2009, 182, 2395-2404.

66. Duncan, J.A.; Gao, X.; Huang, M.T.; O'Connor, B.P.; Thomas, C.E.; Willingham, S.B.; Bergstralh, D.T.; Jarvis, G.A.; Sparling, P.F.; Ting, J.P. Neisseria gonorrhoeae activates the proteinase cathepsin B to mediate the signaling activities of the NLRP3 and ASC-containing inflammasome. J. Immunol. 2009, 182, 6460-6469.

67. Thomas, P.G.; Dash, P.; Aldridge, J.R., Jr.; Ellebedy, A.H.; Reynolds, C.; Funk, A.J.; Martin, W.J.; Lamkanfi, M.; Webby, R.J.; Boyd, K.L.; Doherty, P.C.; Kanneganti, T.D. The intracellular sensor NLRP3 mediates key innate and healing responses to influenza A virus via the regulation of caspase-1. Immunity 2009, 30, 566-575.

68. Abdul-Sater, A.A.; Koo, E.; Hacker, G.; Ojcius, D.M. Inflammasome-dependent caspase-1 activation in cervical epithelial cells stimulates growth of the intracellular pathogen chlamydia trachomatis. J. Biol. Chem. 2009. 
69. Kanneganti, T.D.; Lamkanfi, M.; Kim, Y.G.; Chen, G.; Park, J.H.; Franchi, L.; Vandenabeele, P.; Nunez, G. Pannexin-1-mediated recognition of bacterial molecules activates the cryopyrin inflammasome independent of Toll-like receptor signaling. Immunity 2007, 26, 433-443.

70. Pelegrin, P.; Barroso-Gutierrez, C.; Surprenant, A. P2X7 receptor differentially couples to distinct release pathways for IL-1beta in mouse macrophage. J. Immunol. 2008, 180, 7147-7157.

71. Pelegrin, P.; Surprenant, A. Pannexin-1 mediates large pore formation and interleukin-1beta release by the ATP-gated P2X7 receptor. EMBO J. 2006, 25, 5071-5082.

72. Pelegrin, P.; Surprenant, A. Pannexin-1 couples to maitotoxin- and nigericin-induced interleukin1 beta release through a dye uptake-independent pathway. J. Biol. Chem. 2007, 282, 2386-2394.

73. Koo, I.C.; Wang, C.; Raghavan, S.; Morisaki, J.H.; Cox, J.S.; Brown, E.J. ESX-1-dependent cytolysis in lysosome secretion and inflammasome activation during mycobacterial infection. Cell. Microbiol. 2008.

74. Burckstummer, T.; Baumann, C.; Bluml, S.; Dixit, E.; Durnberger, G.; Jahn, H.; Planyavsky, M.; Bilban, M.; Colinge, J.; Bennett, K.L.; Superti-Furga, G. An orthogonal proteomic-genomic screen identifies AIM2 as a cytoplasmic DNA sensor for the inflammasome. Nat. Immunol. 2009, 10, 266-272.

75. Fernandes-Alnemri, T.; Yu, J.W.; Datta, P.; Wu, J.; Alnemri, E.S. AIM2 activates the inflammasome and cell death in response to cytoplasmic DNA. Nature 2009, 458, 509-513.

76. Hornung, V.; Ablasser, A.; Charrel-Dennis, M.; Bauernfeind, F.; Horvath, G.; Caffrey, D.R.; Latz, E.; Fitzgerald, K.A. AIM2 recognizes cytosolic dsDNA and forms a caspase-1-activating inflammasome with ASC. Nature 2009, 458, 514-518.

77. Roberts, T.L.; Idris, A.; Dunn, J.A.; Kelly, G.M.; Burnton, C.M.; Hodgson, S.; Hardy, L.L.; Garceau, V.; Sweet, M.J.; Ross, I.L.; Hume, D.A.; Stacey, K.J. HIN-200 proteins regulate caspase activation in response to foreign cytoplasmic DNA. Science 2009, 323, 1057-1060.

78. Kankkunen, P.; Rintahaka, J.; Aalto, A.; Leino, M.; Majuri, M.L.; Alenius, H.; Wolff, H.; Matikainen, S. Trichothecene mycotoxins activate inflammatory response in human macrophages. J. Immunol. 2009, 182, 6418-6425.

79. Gross, O.; Poeck, H.; Bscheider, M.; Dostert, C.; Hannesschlager, N.; Endres, S.; Hartmann, G.; Tardivel, A.; Schweighoffer, E.; Tybulewicz, V.; Mocsai, A.; Tschopp, J.; Ruland, J. Syk kinase signalling couples to the Nlrp3 inflammasome for anti-fungal host defence. Nature 2009, 459, 433-436.

80. Joly, S.; Ma, N.; Sadler, J.J.; Soll, D.R.; Cassel, S.L.; Sutterwala, F.S. Cutting Edge: Candida albicans Hyphae Formation Triggers Activation of the Nlrp3 Inflammasome. J. Immunol. 2009.

81. Hise, A.G.; Tomalka, J.; Ganesan, S.; Patel, K.; Hall, B.A.; Brown, G.D.; Fitzgerald, K.A. An essential role for the NLRP3 inflammasome in host defense against the human fungal pathogen Candida albicans. Cell Host Microbe 2009, 5, 487-497.

82. van de Veerdonk, F.L.; Joosten, L.A.; Devesa, I.; Mora-Montes, H.M.; Kanneganti, T.D.; Dinarello, C.A.; van der Meer, J.W.; Gow, N.A.; Kullberg, B.J.; Netea, M.G. Bypassing pathogen-induced inflammasome activation for the regulation of interleukin-1beta production by the fungal pathogen Candida albicans. J. Infect. Dis. 2009, 199, 1087-1096. 
83. Saito, M.; Nishikomori, R.; Kambe, N.; Fujisawa, A.; Tanizaki, H.; Takeichi, K.; Imagawa, T.; Iehara, T.; Takada, H.; Matsubayashi, T.; Tanaka, H.; Kawashima, H.; Kawakami, K.; Kagami, S.; Okafuji, I.; Yoshioka, T.; Adachi, S.; Heike, T.; Miyachi, Y.; Nakahata, T. Disease-associated CIAS1 mutations induce monocyte death, revealing low-level mosaicism in mutation-negative cryopyrin-associated periodic syndrome patients. Blood 2008, 111, 2132-2141.

84. Fujisawa, A.; Kambe, N.; Saito, M.; Nishikomori, R.; Tanizaki, H.; Kanazawa, N.; Adachi, S.; Heike, T.; Sagara, J.; Suda, T.; Nakahata, T.; Miyachi, Y. Disease-associated mutations in CIAS1 induce cathepsin B-dependent rapid cell death of human THP-1 monocytic cells. Blood 2007, 109, 2903-2911.

85. Petrilli, V.; Papin, S.; Dostert, C.; Mayor, A.; Martinon, F.; Tschopp, J. Activation of the NALP3 inflammasome is triggered by low intracellular potassium concentration. Cell Death Differ. 2007, 14, 1583-1589.

86. Cassel, S.L.; Eisenbarth, S.C.; Iyer, S.S.; Sadler, J.J.; Colegio, O.R.; Tephly, L.A.; Carter, A.B.; Rothman, P.B.; Flavell, R.A.; Sutterwala, F.S. The Nalp3 inflammasome is essential for the development of silicosis. Proc. Natl. Acad. Sci. USA 2008, 105, 9035-9040.

87. Cruz, C.M.; Rinna, A.; Forman, H.J.; Ventura, A.L.; Persechini, P.M.; Ojcius, D.M. ATP activates a reactive oxygen species-dependent oxidative stress response and secretion of proinflammatory cytokines in macrophages. J. Biol. Chem. 2007, 282, 2871-2879.

88. Dostert, C.; Petrilli, V.; Van Bruggen, R.; Steele, C.; Mossman, B.T.; Tschopp, J. Innate immune activation through Nalp3 inflammasome sensing of asbestos and silica. Science 2008, 320, 674-677.

89. Ng, G.; Sharma, K.; Ward, S.M.; Desrosiers, M.D.; Stephens, L.A.; Schoel, W.M.; Li, T.; Lowell, C.A.; Ling, C.C.; Amrein, M.W.; Shi, Y. Receptor-independent, direct membrane binding leads to cell-surface lipid sorting and syk kinase activation in dendritic cells. Immunity 2008, 29, 807-818.

90. Piccini, A.; Carta, S.; Tassi, S.; Lasiglie, D.; Fossati, G.; Rubartelli, A. ATP is released by monocytes stimulated with pathogen-sensing receptor ligands and induces IL-1beta and IL-18 secretion in an autocrine way. Proc. Natl. Acad Sci USA 2008, 105, 8067-8072.

91. Netea, M.G.; Nold-Petry, C.A.; Nold, M.F.; Joosten, L.A.; Opitz, B.; van der Meer, J.H.; van de Veerdonk, F.L.; Ferwerda, G.; Heinhuis, B.; Devesa, I.; Funk, C.J.; Mason, R.J.; Kullberg, B.J.; Rubartelli, A.; van der Meer, J.W.; Dinarello, C.A. Differential requirement for the activation of the inflammasome for processing and release of IL-1beta in monocytes and macrophages. Blood 2009, 113, 2324-2335.

92. Silverman, W.R.; de Rivero Vaccari, J.P.; Locovei, S.; Qiu, F.; Carlsson, S.K.; Scemes, E.; Keane, R.W.; Dahl, G. The pannexin 1 channel activates the inflammasome in neurons and astrocytes. J. Biol. Chem. 2009, 284, 18143-18151.

93. Nakamura, Y.; Kambe, N.; Saito, M.; Nishikomori, R.; Kim, Y.G.; Murakami, M.; Nunez, G.; Matsue, H. Mast cells mediate neutrophil recruitment and vascular leakage through the NLRP3 inflammasome in histamine-independent urticaria. J. Exp. Med. 2009, 206, 1037-1046. 
94. Ghiringhelli, F.; Apetoh, L.; Tesniere, A.; Aymeric, L.; Ma, Y.; Ortiz, C.; Vermaelen, K.; Panaretakis, T.; Mignot, G.; Ullrich, E.; Perfettini, J.L.; Schlemmer, F.; Tasdemir, E.; Uhl, M.; Genin, P.; Civas, A.; Ryffel, B.; Kanellopoulos, J.; Tschopp, J.; Andre, F.; Lidereau, R.; McLaughlin, N.M.; Haynes, N.M.; Smyth, M.J.; Kroemer, G.; Zitvogel, L. Activation of the NLRP3 inflammasome in dendritic cells induces IL-1beta-dependent adaptive immunity against tumors. Nat. Med. 2009, 15, 1170-1178.

(C) 2010 by the authors; licensee Molecular Diversity Preservation International, Basel, Switzerland. This article is an open-access article distributed under the terms and conditions of the Creative Commons Attribution license (http://creativecommons.org/licenses/by/3.0/). 